\title{
On the question of using solid electrodes in the electrolysis of cryolite-alumina melts. Part 3. Electric field distribution on the electrodes
}

\author{
Evgeniy S. Gorlanov ${ }^{\star}$, Andrey A. Polyakov** \\ ${ }^{*}$ EXPERT-AL LLC, St. Petersburg, Russia \\ ${ }^{*}$ Saint-Petersburg Mining University, St. Petersburg, Russia
}

\begin{abstract}
The aim of this work is to identify the theoretical limitations of molten salts electrolysis using solid electrodes to overcome these limitations in practice. We applied the theory of electric field distribution on the electrodes in aqueous solutions to predict the distribution of current density and potential on the polycrystalline surface of electrodes in molten salts. By combining the theoretical background of the current density distribution with the basic laws of potential formation on the surface of the electrodes, we determined and validated the sequence of numerical studies of electrolytic processes in the pole gap. The application of the method allowed the characteristics of the current concentration edge effect at the periphery of smooth electrodes and the distribution of current density and potential on the heterogeneous electrode surface to be determined. The functional relationship and development of the electrolysis parameters on the smooth and rough surfaces of electrodes were established by the different scenario simulations of their interaction. It was shown that it is possible to reduce the nonuniformity of the current and potential distribution on the initially rough surface of electrodes with an increase in the cathode polarisation, alumina concentration optimisation and melt circulation. It is, nonetheless, evident that with prolonged electrolysis, physical and chemical inhomogeneity can develop, nullifying all attempts to stabilise the process. We theoretically established a relationship between the edge effect and roughness and the distribution of the current density and potential on solid electrodes, which can act as a primary and generalising reason for their increased consumption, passivation and electrolytic process destabilisation in standard and low-melting electrolytes. This functional relationship can form a basis for developing the methods of flattening the electric field distribution over the anodes and cathodes area and, therefore, stabilising the electrolytic process. Literature overview, laboratory tests and theoretical calculations allowed the organising principle of a stable electrolytic process to be formulated the combined application of elliptical electrodes and the electrochemical micro-borating of the cathodes. Practical verification of this assumption is one direction for further theoretical and laboratory research.
\end{abstract}

Keywords: electrolysis, solid electrodes, physical imperfection, cathode passivation, inert anodes, wettable cathodes

For citation: Gorlanov ES, Polyakov AA. On solid electrode application for cryolite-alumina melt electrolysis. Part 3. Electric field distribution on electrodes. Vestnik Irkutskogo gosudarstvennogo tehnicheskogo universiteta $=$ Proceedings of Irkutsk State Technical University. 2021;25(2):235-251. https://doi.org/10.21285/1814-3520-2021-2-235-251

\section{К вопросу о применении твердых электродов для электролиза криолитоглиноземных расплавов. Часть 3. Распределение электрического поля на электродах}

\author{
(C) Е.С. Горланов*, А.А. Поляков ${ }^{* *}$ \\ *ООО «ЭКСПЕРТ-АЛ», г. Санкт-Петербург, Россия \\ ${ }^{* *}$ Санкт-Петербургский горный университет, г. Санкт-Петербург, Россия
}

\begin{abstract}
Резюме: Цель - выявление теоретических ограничений электролиза расплавленных солей с применением твердых электродов для их преодоления на практике. Приложение теории распределения электрического поля на электродах в водных растворах к прогнозированию распределения плотности тока и потенциала на поликристаллической поверхности электродов в расплавленных солях. Сопряжением теоретических основ распределения плотности тока с тривиальными законами формирования потенциала на поверхности электродов получены основания и определена последовательность численных исследований процессов электролиза в междуполюсном зазоре. Применение метода позволило установить особенности краевого эффекта концентрации тока на периферии гладких электродов и распределения плотности тока и потенциала на неоднородной поверхности


электродов. Моделированием различных сценариев взаимодействия параметров электролиза установлена их функциональная связь и проявление на гладкой и шероховатой поверхности электродов. Показано, что с увеличением поляризации катода, оптимизацией концентрации глинозема и циркуляции расплава можно снизить неоднородное распределение тока и потенциала на поверхности электродов с исходной шероховатостью. При этом очевидно, что при длительном электролизе могут развиваться физическая и химическая неоднородности, что аннулирует все попытки стабилизировать процесс. Теоретически установленная взаимосвязь краевого эффекта и шероховатости с распределением плотности тока и потенциала на твердых электродах может выступать первичной и обобщающей причиной их повышенного расхода, пассивации и дестабилизации электролиза в стандартных и легкоплавких электролитах. И в то же время эта функциональная связь может служить основой для разработки способов выравнивания распределения электрического поля по площади анодов и катодов и, следовательно, стабилизации электролитического процесса. Литературный обзор, лабораторная практика и теоретические расчеты позволили сформулировать принцип организации стабильного электролитического процесса комплексное применение электродов эллиптической формы и электрохимическое микроборирование катодов. Практическое подтверждение этого предположения - одно из возможных направлений последующих теоретических и лабораторных исследований.

Ключевые слова: электролиз, тверды электроды, физическая неоднородность, пассивация катода, инертные аноды, смачиваемые катоды

Для цитирования: Горланов Е.С., Поляков А.А. К вопросу о применении твердых электродов для электролиза криолитоглиноземных расплавов. Часть 3. Распределение электрического поля на электродах. Вестник Иркутского государственного технического университета. 2021. Т. 25 . № $2 . \quad$ С. $235-251$. https://doi.org/10.21285/1814-3520-2021-2-235-251

\section{INTRODUCTION}

Potential distribution and, to an even greater extent, current distribution are of great importance for the technical applications in electrochemistry. The uneven current distribution leads to an uneven thickness distribution of the deposited coating. Fig. 1 shows the crosssection of copper sediment on the metallic substrate (see). The thickness of the $\mathrm{Cu}$ coating increases from the recess uphill the pick and reaches the maximum on the crest of a serrated profile. Moreover, a large build-up of deposited copper is observed at the corner joint of the inclined and horizontal surfaces. This indicates an increasing current density towards the asperity tip and on the outer edges during the electrolytic process.

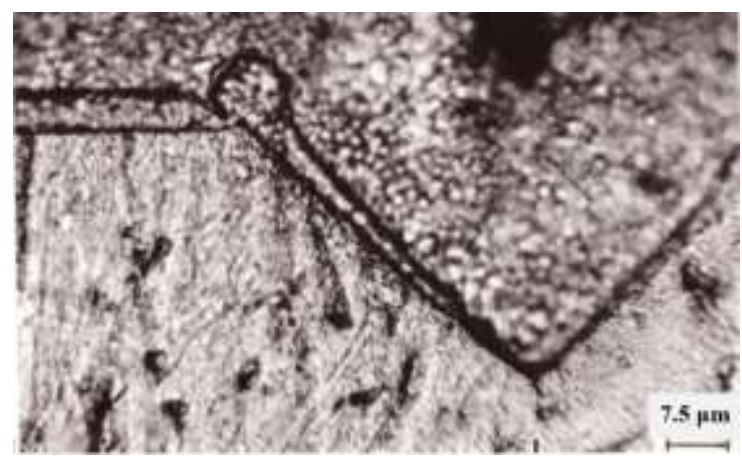

Fig. 1. Copper coating on a pinion profile [1] Puc. 1. Медное покрытие на зубчатом профиле [1]

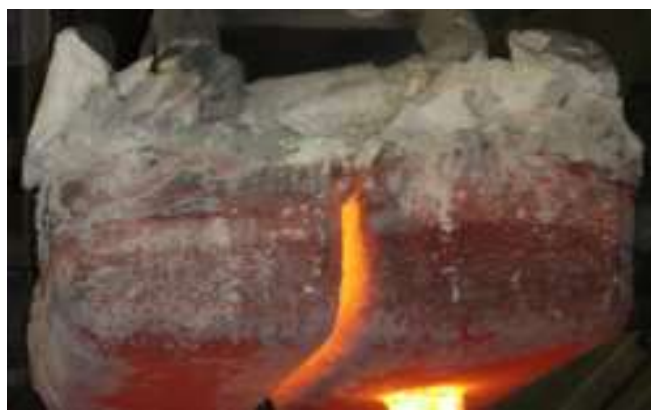

Fig. 2. Electrochemical local wear of the anodes along the edges around the perimeter

Puc. 2. Электрохимический локальный износ анодов по ребрам периметра

Similar phenomena occur on the anode. For example, during the electrolytic production of aluminium, the carbon anodes are consumed at a higher rate on the edges around the perimeter (fig. 2), resulting in the changes of actual integrated current density and interelectrode gap and increased electrode consumption. Similarly, for the inert anodes, the observed corrosion occurs more rapidly where current density localises.

In other words, without dwelling on the detail of the technological aspects, the electric field distribution theory is one of the fundamental principles of electrochemical engineering. Therefore, it is important to understand and predict the phenomena, which influence the current and potential distribution. The theory of these 
processes on the electrodes in the aqueous solutions is extensively discussed in the books of J. Newman, N. Ibl, Y. Gamburg, A. Baraboshkin [2-5]. Since the electrochemical laws are valid for the electrolysis of the molten salts, we will attempt, to the extent necessary, to use this theory to calculate the electric field distribution on the cathode as applied to the electrolysis of cryolite-alumina melts. The current and potential distribution on the anode follows the same laws (considering the corresponding processes, their kinetic parameters and polarisation effects) and will not be analytically considered here.

\section{THEORETICAL JUSTIFICATION OF THE CALCULATIONS}

The main factors influencing the electric field distribution in the electrode space are [2-5]:

- geometry and the hydrodynamic conditions of the system;

- electrical conductivity of electrolyte and electrodes;

- the profile characteristic and surface condition of electrodes; trodes.

- the degree of polarisation of the elec-

On the smooth or partially smooth surface of electrodes, for example, metallic one, the field and current density distribution is relatively uniform. However, there is a pronounced edge effect of current concentration at the edges, namely an increase in its density (fig. 3).

The same applies to structural elements (edges, rods, peaks and joints) of perforated or grooved cathodes and anodes (fig. 4). This is associated with the increasing electrolyte crosssection between the anode and the cathode in the direction of the edge surfaces and, accordingly, the decreasing electrical resistance at a distance of the pole gap.

The electric field distribution is strongly affected by the state of the electrode surface, including chemical heterogeneity (heterogeneous composition, impurities) and physical heterogeneity (roughness), inherent in all polycrystalline products, including hot-pressed and cast ones. On this kind of surface, the local current densities at the peaks and recesses are different, even if the macroscopic current distribution in a given area is entirely uniform. Since the electrical conductivity of the electrode is higher than that of the electrolyte, the electric field near the interface is non-uniform. The equipotential surfaces reproduce the topography of the interface, and the current lines are perpendicular to this surface (fig. 5).

Therefore, the heterogeneity of the electric field leads to uneven current density distribution on the surface.

Integrating the mass and charge transport equation is the most general theoretical approach to solving the problem of current and potential distribution. The equation can rarely be solved with respect to the potential (or concentration) with all parameters considered. Therefore, the moderately simplified versions of this equation are used, resulting in the Laplace or Fick equations. The nature of the approximation depends on the type of the distribution (primary, secondary or tertiary).

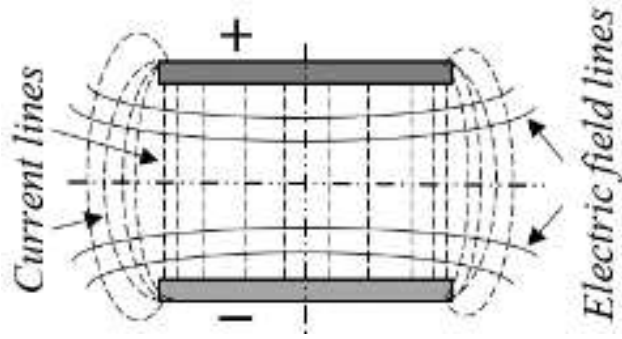

Fig. 3. Equipotential lines and current lines in the anode-cathode system

Рис. 3. Эквипотенциальные линии и линии тока в системе анод-катод

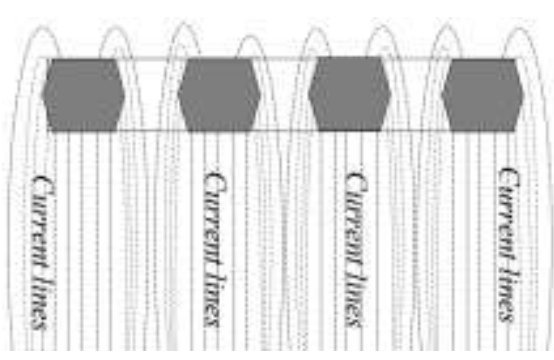

Fig. 4. Current lines on a perforated electrode Puc. 4. Линии тока на перфорированном электроде 


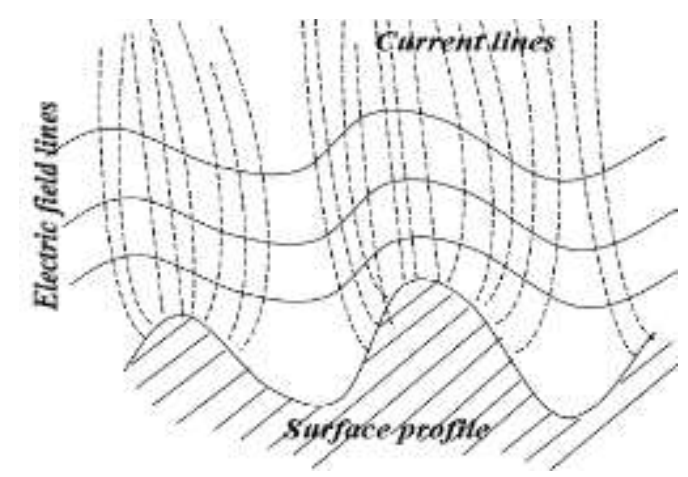

Fig. 5. Equipotential lines and current lines near the electrode

Рис. 5. Эквипотенциальные линии и линии тока вблизи электрода

In the simplest case, one or both electrodes are non-polarisable, which corresponds to the primary field and current density distribution on this electrode. This distribution is the least uniform for the indicated geometry of the system. However, the surface of the melt next to the electrode is equipotential, and the current lines corresponding to the potential gradient are normal to the surface (see fig. 3-5).

If one considers the electrode polarisation the charge transfer overpotential $\eta_{\text {trans }}$, then the secondary field and current distribution takes place. The absence of the diffusion overpotential means that there are no noticeable concentration gradients or other mass transfer limitations in the solution. The charge transfer overpotential at the low current density (the electrode potential is near the equilibrium value) is determined by the equation: $\eta_{\text {trans }}=i \cdot \beta_{2}$, where the polarisation at the secondary distribution $\beta_{2}$ is equal to [5]:

$$
\beta_{2}=\frac{R \cdot T}{n \cdot F \cdot i_{0}}
$$

where $n$ is the number of electrons involved in the reaction; $R$ is the gas constant, $\mathrm{J} / \mathrm{mol} \cdot \mathrm{K} ; T$ is the temperature of the process, $\mathrm{K} ; F$ is the Faraday constant, $\mathrm{J} / \mathrm{mol} ; i_{0}$ is the exchange current density, $\mathrm{A} / \mathrm{cm}^{2}$.

The exchange current is the rate of an electrochemical process in the forward and reverse directions at the equilibrium potential. As follows from equation (1), with increasing $i_{0}$ the polarisation and charge transfer overpotential decrease. If $i_{0}>>i$, the overpotential $\eta_{\text {trans }}$ is close to zero, and the process is at equilibrium (reversible or non-polarisable). Usually, the cathodic exchange current values in the molten salts are high - from one to hundreds of amperes per square centimetre $\left(\mathrm{A} / \mathrm{cm}^{2}\right)$ owing to the process acceleration at high temperatures. For the electrolysis of the cryolite-alumina melts $i_{0}$ is approximately $20 \mathrm{~A} / \mathrm{cm}^{2}[6,7]$.

When the concentration field near the working electrode is considered, the corresponding solution to the problem results in a tertiary current distribution. Here, the metal deposition rate is determined by transport processes in the near-electrode diffusion layer. Tafel dependence between the current and the overpotential is introduced into the calculations to converge to the tertiary distribution: $\eta=a+b$ lgi, where the polarisation is approximately equivalent to the following value [4]:

$$
\beta_{3}=\frac{R \cdot T}{n F i_{\mathrm{A}}}
$$

where $i_{A}$ is the integrated or geometric current density.

For the smooth electrodes constituting the hypothetical infinitely long plate with a width of $2 B(-B<x<B)$, the solution of the twodimensional Laplace equation based on the conformal mapping method for the primary potential distribution reveals the dependence of local current density $i_{S}$ on the coordinate $\boldsymbol{x}[4]$ :

$$
i_{S}=i_{A}\left(1-\frac{x^{2}}{B^{2}}\right)^{-1 / 2}
$$

According to equation (3), the current density $i_{S}$, increases from the middle of the electrode to 
its periphery and tends to infinity at the edges. This owes to all the electric lines of force from an infinitely large area concentrated here $|x|>B$ (see Fig. ).

For the secondary and tertiary current distribution on smooth electrodes, their polarisation $\beta_{2(3)}$, should be considered as well as the electrical resistance of the electrolyte $\rho_{\text {bath }}$ in the pole gap $I_{x}[4]$ :

$$
i_{S}=i_{A} \cdot \exp \left[\frac{k \cdot x}{B \cdot\left(\frac{\beta_{2(3)}}{\rho_{\text {bath }} \cdot l_{x}}\right)}\right] .
$$

In this equation, the coefficient $k$ characterises the dependence of $I_{x}$ on the coordinate $x: k$ $=d l / d x$ or in the first approximation $k=d l n l / d x$.

While discussing the electric field distribution on the rough surface, we will consider its profile described by the curve $x_{S}(y)$. The current distribution is set by the electric field between the electrode and the rough surface of the counter electrode with a sinuous profile with an amplitude less than the wavelength $A<L$ (fig. 6). The representation of the surface profile as a sine wave allows a variety of periodic shapes with different steps to be generated. In addition, the sine wave has no corner points, therefore the infinitely high current densities often observed at the corners are avoided.

In case of the constant polarisation $\beta$ simultaneous solution of Laplace equation for the electrolyte and the cathodic surface profile $x_{S}=A \cdot \cos (2 \pi / L)$ allows the local current density distribution to be calculated $i_{S}[2,4,5]$ :

$$
i_{S}=i_{A}\left[1+\frac{\left(\frac{2 \pi}{L}\right)\left(\rho_{b a t h}-\rho_{A l}\right)}{\rho_{b a t h}+\rho_{A l}+\left(\frac{2 \pi}{L}\right) \beta} \cdot A_{S} \cdot \cos \left(\frac{2 \pi y}{L}\right)\right]
$$

In this equation, $i_{A}$ is the integrated or geometric current density. This assumption is acceptable since we believe that the total current passes through the electrolyte cross-section in the pole gap with an electrical resistance $\rho_{\text {bath, }}$ $\Omega \cdot \mathrm{cm}$. We also consider the electrical resistance of liquid aluminium $\rho_{A l}, \Omega \cdot \mathrm{cm} ; L$ is the sinuous wavelength or the elemental periodic physical defects, cm; $A_{S}$ is the current roughness amplitude varying during the period $L$ in the limits from $-A$ to $+A, \mathrm{~cm} ; y$ is the current coordinate on the " $y$ » axis across the rough surface, $\mathrm{cm}$.

The analysis of equation (5) shows that the value of polarisation $\beta$ essentially affects the uniformity of current distribution over the initial or changing rough surface. The greater the polarisation of the surface of the electrode, the more uniform will be the current distribution on the electrode plane. Here it is important to address the term "polarisation". During the electrolysis, the current passes through the electrode and the potential deviates from the equilibrium values. A change in the electrode potential is called electrode polarisation and is expressed as the derivative of the overpotential on the current density: $\beta=d \eta / d i$. This relation, i.e., polarisation, is technically the resistance per the square centimetre of the electrode area $\left(\Omega \cdot \mathrm{cm}^{2}\right)$. It can be determined as polarisation resistance $R$. If this resistance represents the slow charge transfer through the interface, it relates to the electrode kinetics and can be called charge transfer resistance $R_{\text {trans. }}$. When $R$ is associated with the slow ion transport through the near-electrode layer, it can be called the diffusion resistance of the potential-determining components $R_{D}$. Consequently, polarisation plays the role of a levelling additive in the electrolyte composition, widely used in electrometallurgy in aqueous media.

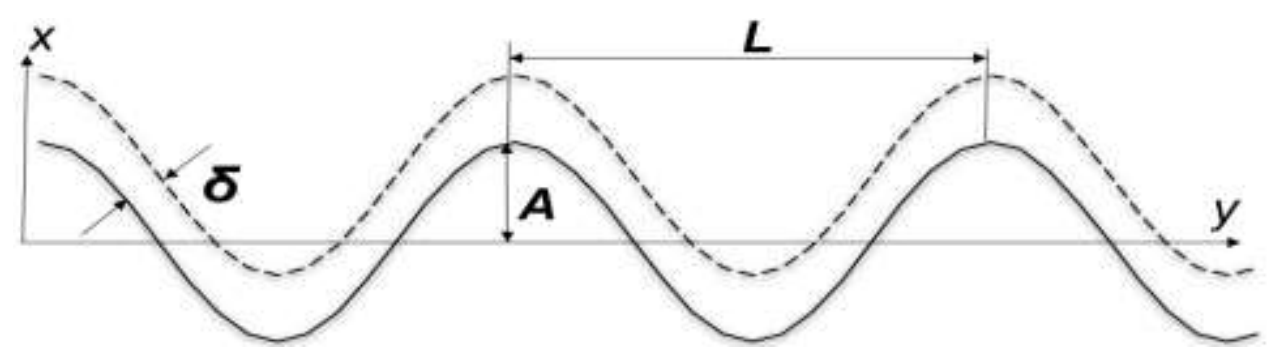

Fig. 6. Sinuous surface profile with a diffusion layer $\delta$

Рuc. 6. Синусоидальный профиль поверхности с диффузионным слоем $\delta$ 
These additives precipitate on the roughness crests, increasing the local surface resistance. Thus, the current distribution levelling over the cathode is achieved. Therefore, the polarisation of any kind (kinetic, transport, crystallisation and other) could be beneficial to some extent for the stabilisation of electrode processes and electrolysis. It is limited by maximum current density.

However, what happens when the maximum current density $i_{p}$ is achieved for aluminium? It is well known that without a change in the total current, the cathode potential shifts sharply to the electronegative side until the most electronegative impurities discharge. Their deficiency leads to the subsequent shift of the potential to the background decomposition values, i.e., electrolyte. However, the impurities discharge of and, what is more, the decomposition of aluminium or cryolite fluorides occur at higher cathodic polarisation, indicating the stable, gradual passivation process, i.e., the isolation of electrode. This unfavourable scenario can develop on the anode as well. However, in this case, the current density on the peaks and sharp edges of physical heterogeneity will lead to the fluorine ions discharge and the evolution of fluorocarbons on the carbon anode and of fluorine on the inert one (or to the electrochemical dissolution of the anode involving fluorine ions). In the first case, even with the stable electrolysis in the best-case scenario, an unfavourable environmental situation is created in the work area. In the other case, the chemical and electrochemical corrosion of the inert anode increases. These undesirable processes are highly probable when using polycrystalline or cast electrodes, anodes and cathodes, thus requiring practical and theoretical research. This study is the first attempt done in this direction.

The description of the potential distribution on a rough surface reduces to solving the Fick equation for concentration distribution of a substance in the diffusion layer. In the considerably diluted solutions, the diffusion equation can be represented as follows [2, 4, 5]:

$$
\frac{\partial c}{\partial t}=D\left(\frac{\partial^{2} c}{\partial x^{2}}+\frac{\partial^{2} c}{\partial y^{2}}+\frac{\partial^{2} c}{\partial z^{2}}\right) .
$$

Since we examine the kinetics of the pro- cesses in the flat electrode system - the melt, the diffusion can be considered linear, as follows:

$$
\frac{\partial c}{\partial t}=D \frac{\partial^{2} c}{\partial x^{2}}
$$

where $x$ is the coordinate perpendicular to the electrode; the concentration gradient in the near-electrode layer of a certain thickness $\delta$ is constant (see fig. 6), i.e., the concentration changes linearly (Nernst assumption):

$$
\frac{d c}{d x}=\text { const }=\frac{c_{0}-c_{S}}{\delta} .
$$

Then the electrolysis rate is equal to the diffusion transport rate or the diffusion current $i_{S}[6]$ :

$$
i_{S}=D n F \frac{d c}{\partial x}=n F \frac{D}{\delta}\left(C_{0}-C_{S}\right),
$$

where $D$ is the diffusion coefficient, $\mathrm{cm}^{2} / \mathrm{s} ; \delta$ is the thickness of the diffusion layer, $\mathrm{cm} ; C_{0}$ and $C_{S}$ are the ion concentration in the melt volume and at the surface of the electrode, respectively, $\mathrm{mol} / \mathrm{cm}^{3}$.

As the current density increases, $C_{S}$ decreases, and the highest possible current at $C_{S} \rightarrow 0$ approaches the limiting diffusion $\boldsymbol{i}_{\text {lim }}$ :

$$
i_{l} i_{\text {lim }}=n F \frac{D}{\delta} C_{0} .
$$

The concentration of the potentialdetermining ions on the surface does not reach zero and can be determined by solving the equation (9) for $C_{S}$ :

$$
\mathrm{C}_{S}=\mathrm{C}_{0}-\frac{i_{S} \cdot \delta}{n F D} .
$$

The fractional expression on the right side of the equation (11) is the current ion concentration immediately at the sinuous surface (recesspeak). Hence, the cathode potential for the dilute solutions determined as:

$$
E=E_{p}^{0}+\frac{R T}{n F} \ln \mathrm{C}_{S}
$$


can be expressed as follows ${ }^{1}$ :

$$
E=E_{p}^{0}+\frac{R T}{n F} \ln \left(C_{0}-\frac{i_{S} \cdot \delta}{n F D}\right),
$$

where $E_{p}^{0}$ is the standard decomposition voltage (equilibrium potential) of the saturated solution of the potential-determining ions in the electrolyte using carbon $(-1,180 \mathrm{~V})$ or inert $(-2,180 \mathrm{~V})$ anode at $965^{\circ} \mathrm{C}$. Electrode potential $E$ is the decomposition voltage at the current concentration gradient of potential-determining ions in the diffusion layer $\delta$. If in equation (13) the current is equal to zero $i_{S}=0$, then the entire system and the potential are equilibrium at the given concentration $c_{0}$ :

$$
E_{p}=E_{p}^{0}+\frac{R T}{n F} \ln C_{0}
$$

Since in the actual system the same equilibrium potential establishes for all processes on the anode and cathode, the difference between the $E$ and $E_{r}$ potentials represents the concentration overpotential of the current process on a specific electrode, cathode $\eta_{D C}$ or anode $\eta_{D A}$ :

$$
\eta_{D C(D A)}=\frac{R T}{n F} \ln \left(1-\frac{i_{S}}{i_{l i m}}\right) .
$$

Equation (13) can be used to calculate the potential distribution depending on the actual current density $i_{S}$ and fixed values of the bulk concentration of the potential-determining ions $C_{0}$, the transfer coefficient $D$ and diffusion layer thickness $\delta$. For the electrolysis of the molten salts, $\delta$ usually ranges from 0.1 to $1 \mathrm{~mm}$ [6]. Convective stirring and gas generation at the anode and gas-lifting in the melt, in particular, reduce this value by an order of magnitude. On a rough surface with a defect height of $H_{\text {def }}=2 A>\delta$, the diffusion layer follows the profile equally ac cessible for diffusion everywhere (see fig. 6).

Thus, the sequence of analytical calculations is as follows:

The calculation of current density distribution $i_{s}$ on a given surface profile according to equations (3)-(5).

The following conditions can be simulated: the primary distribution, i.e., no polarisation when $\beta_{1}=0$, secondary $\beta_{2}$, or tertiary $\beta_{3}$ distributions according to equations (1) and (2), respectively.

The potential distribution $E$ is calculated based on the current values of the current density $i_{S}$ on the surface according to equation (13).

\section{CALCULATION RESULTS AND DISCUSSION}

In the calculations, the standard characteristics of the NaF-AIF-Al $\mathrm{O}_{3}$ melts at a temperature of $965^{\circ} \mathrm{C}$ were used. It is important to note that the calculation results are not absolute at the given parameters and in the approximation of smooth and sinuous profiles, but adequately reflect trends in the current density and potential distribution on the surface of electrodes. This provides a better understanding of the work of electrodes under near-real conditions. Therefore, the first model at $\boldsymbol{\beta} \mathbf{1}=\mathbf{0}$ assumes the $a b$ sence of the charge transfer overpotential $\eta_{\text {trans }}$ and the alumina concentration in the electrolyte close to saturation. The other model suggests the standard operation of the electrolytic cell under the diffusion kinetics at $\beta_{3}$. Here we stress again that the next section presents the calculation results for the cathode surface only. Nevertheless, they characterise qualitatively the electric field distribution on the anode as well.

\section{Smooth electrodes}

The current density is and potential $\boldsymbol{E}$ are distributed relatively uniformly on the inner surface of smooth electrodes but increase sharply around the perimeter of the cathode (fig. 7).

\footnotetext{
${ }^{1}$ It is worth noticing that for the anode process (in case of anodic dissolution of the electrode) in equation (9) the bulk and surface concentrations interchange their positions $i_{S}=D n F \frac{d c}{\partial x}=n F \frac{D}{\delta}\left(C_{S}-C_{0}\right)$; thus, the anode potential will be expressed by the following equation $E=E_{p}^{0}+\frac{R T}{n F} \ln \left(C_{0}+\frac{i_{S} \delta}{n F D}\right) /$ Заметим, что для анодного процесса (анодного растворения электрода) в уравнении (9) объемная и поверхностная концентрации поменяются местами $i_{S}=D n F \frac{d c}{\partial x}=$ $n F \frac{D}{\delta}\left(C_{S}-C_{0}\right)$ и анодный потенциал будет выражаться уравнением: $E=E_{p}^{0}+\frac{R T}{n F} \ln \left(C_{0}+\frac{i_{S} \cdot \delta}{n F D}\right)$.
} 


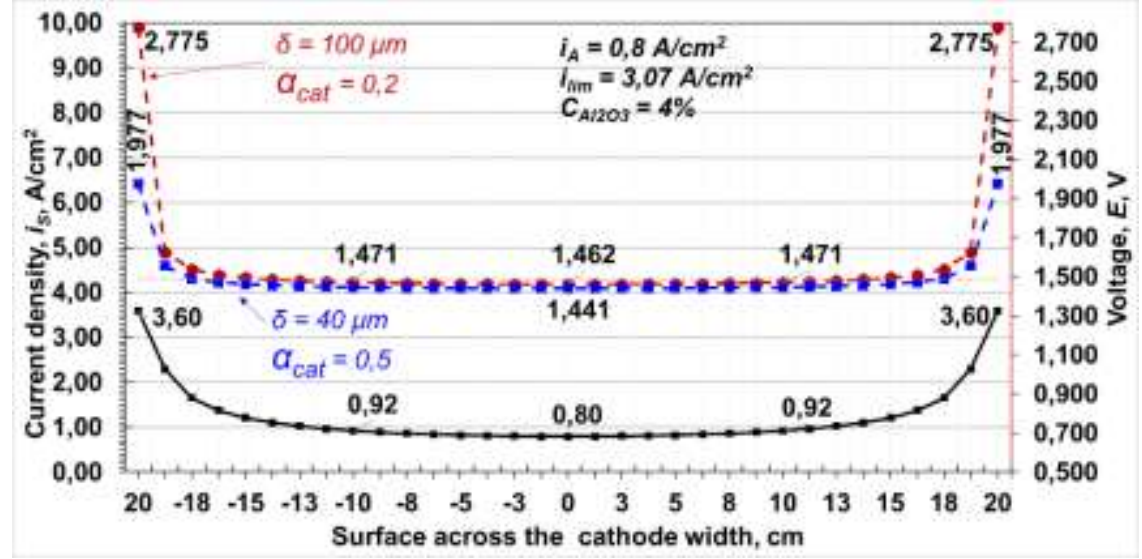

Fig. 7. Distribution of is (solid) and $E$ (dashed) on smooth electrodes in the approximation of the primary distribution Puc. 7. Распределение is (сплошная) и $E$ (пунктирная) на гладких электродах в приближении первичного распределения

At $\beta_{1}$ with the weakly polarised electrodes, the current density (solid line) on edges and peripheral surface exceeds the geometrical current density on the inner surface by several times and reaches $1,50 \div 3,6 \mathrm{~A} / \mathrm{cm}^{2}$. The cathode potential (dashed lines) on the periphery can vary significantly depending on the conditions of the hydrodynamic stirring and the electroactive ions transfer. As the diffusion layer thickness $\delta$ increases and the transference number $\alpha_{c a t}$ decreases approximately by two-fold, the potential increases from $1.6 \div 2.0 \mathrm{~V}$ to $1.7 \div 2.8 \mathrm{~V}$. For the cathode, this process acceleration leads to a transition from a local discharge of electronegative impurities, for example, calcium, to the passivation of peripheral regions by the electrolyte components. For the anode, the consequences of the edge effect involve the transition from the oxygen ions discharge to that of fluorine and accelerated chemical and electrochemical consumption.

These negative effects are mitigated by the diffusion control of electrolysis with tertiary $\beta_{3}$ electric field distribution (fig. 8). With the same integrated current density of $0.8 \mathrm{~A} / \mathrm{cm}^{2}$ on the periphery, the current density increases by only two-fold. However, certain conditions can, to some extent, complicate the electrolysis process in the peripheral areas of the electrodes. For example, if the electrolyte viscosity increases or stirring conditions deteriorate and, hence, $\delta$ increases from 70 to $100 \mu \mathrm{m}$, the potential at the electrode edges can reach the level of impurity discharge at the cathode (see fig. 8) or selective dissolution of the anode components.

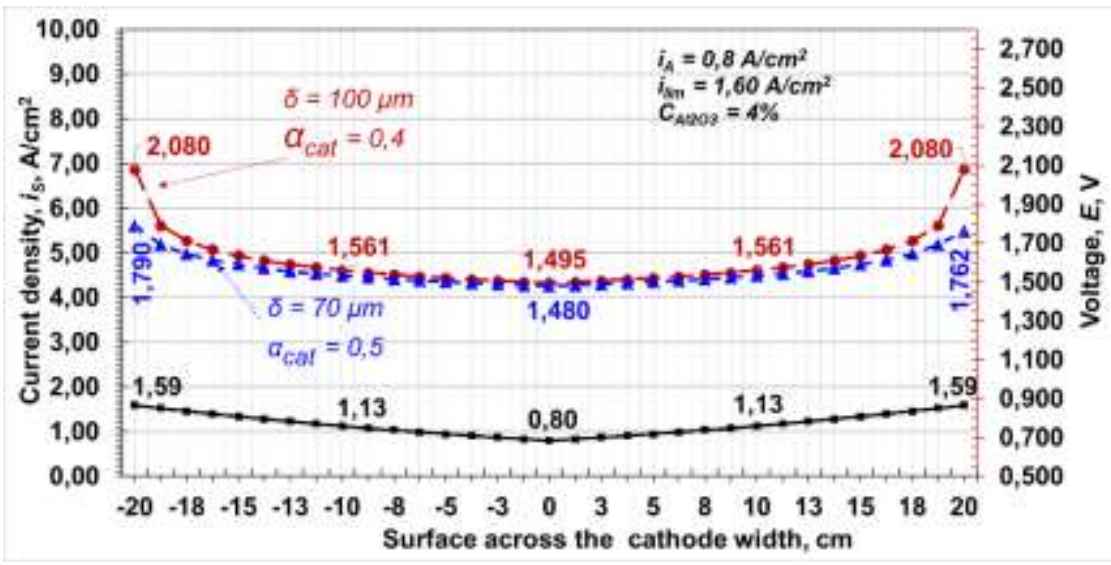

Fig. 8. Distribution of $i_{S}$ (solid) and $E$ (dashed) on smooth electrodes using the approximation of the primary distribution Puc. 8. Распределение is (сплошная) u $E$ (пунктирная) на гладких электродах в приближении третичного распределения 
The addressed particularities of the edge effect on solid electrodes are fully applicable to the perforated and grooved cathodes and anodes. The current and potential concentration on the edges, side surfaces of the openings and rods increases the cathode passivation or the anode consumption proportional to their total area.

\section{Rough electrodes}

Firstly, we compared the operating modes of a polycrystalline cathode without significant polarisation and under the diffusion control of cathode processes. The figure below shows the current density and potential distribution for a given cathode surface profile $x_{S}=A \cos (2 \pi / L)$ under the indicated parameters (fig. 9). Under the diffusion control, $\beta_{3}$, the current density distribution (solid lines) and the corresponding potential distribution (dashed lines) are within the limits that satisfy the stable aluminium reduction on a solid carbon cathode.
The distribution heterogeneity, the current density and potential values sharply increase without activation and diffusion overpotentials (sine wave $\beta_{1}$ on fig. 9). On the defect peaks, the actual current density is approximately 2 $\mathrm{A} / \mathrm{cm}^{2}$, at which the cathode potential reaches and exceeds the ionic discharge values of calcium of $1.600 \div 1.890 \mathrm{~V}$. The subsequent potential jumps up to the electrolyte components discharge occurs with the calcium deficit or its absence in the electrolyte.

The surface roughness of the solid electrodes significantly limits the electrolysis intensification. The slight increase in current density proportionally changes the potential distribution at fixed surface parameters. These changes manifest a pronounced tendency to shift the potential to the electronegative side with an increase in the current density at the electrode (fig. 10).

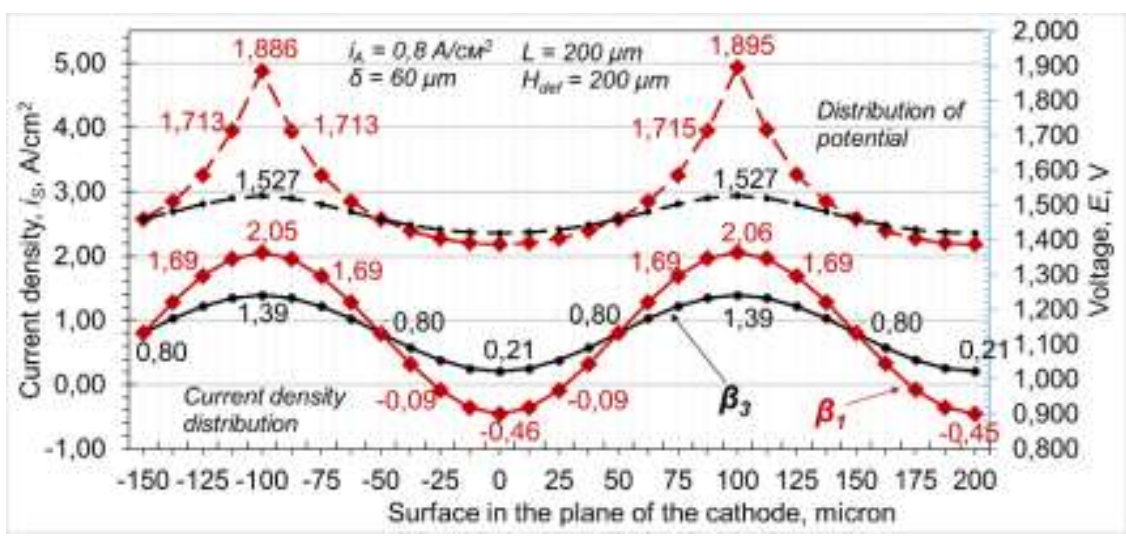

Fig. 9. Distribution of $i_{S}$ (solid) and $E$ (dashed) at $\beta_{1}$ and $\beta_{3}$

Puc. 9. Распределение is (сплошная) и $E$ (пунктирная) при $\beta_{1} u \beta_{3}$

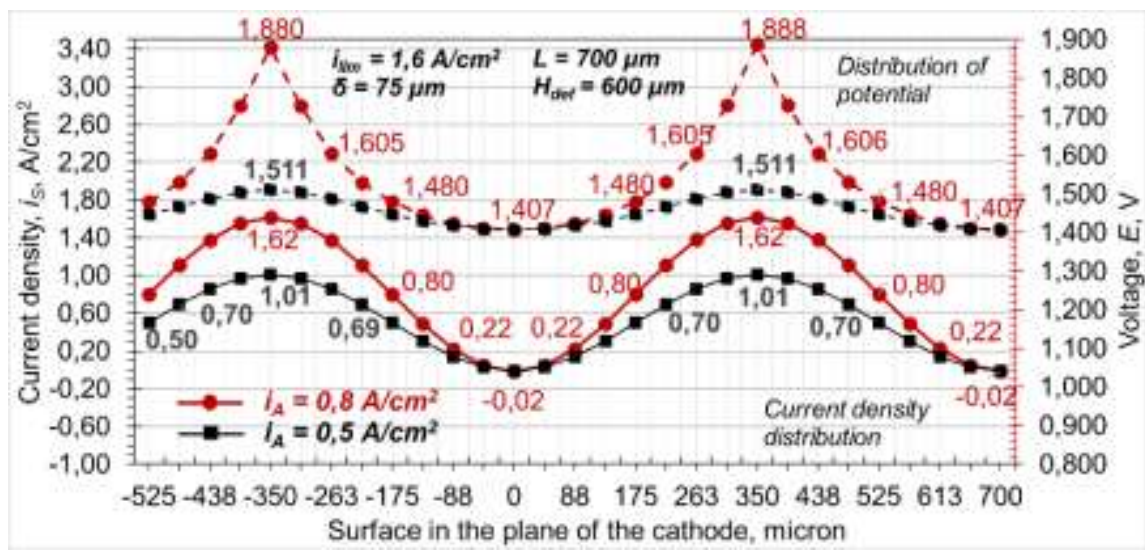

Fig. 10. Influence of the initial $i_{A}$ value on the distribution of $i_{S}$ (solid) and $E$ (dashed) Puc. 10. Влияние исходной $i_{A}$ на распределение і (сплошная) и $E$ (пунктирная) 
We fitted the alumina concentration and the stirring conditions $(0$ and $\delta$ ) to the parameters of the cathode roughness in a way that the increase in the integral current density $i_{A}$ above $0.5 \mathrm{~A} / \mathrm{cm}^{2}$ led to an increase in the real current density is at the defect peaks to the values close to the limiting values $i_{\text {lim. }}$. Under these conditions, a local potential jump creates conditions for the simultaneous discharge of the impurities that are more electronegative than aluminium.

Fig. 11 shows the calculation results simulating the diffusion limitations of the cathode process with an increase in the integrated current density.

At the roughness up to $600 \mu \mathrm{m}$, the current density $i_{A}=0.5 \mathrm{~A} / \mathrm{cm}^{2}$ and the intensive melt stirring $(\delta=75 \mathrm{~m})$, the cathode process approaches limiting density only at the alumina concentration of 2 wt.\%. However, at $i_{A}=0.8 \mathrm{~A} / \mathrm{cm}^{2}$ electrolysis can be destabilised at the alumina concentration of $3 \mathrm{wt} . \%$. Increasing the integral current density up to $1 \mathrm{~A} / \mathrm{cm}^{2}$ on a polycrystalline surface allows a stable process only with alumina concentrations above 4 wt.\%. Indeed, the electrolysis conditions differ in highly soluble electrolytes (up to 10-15 wt.\%) and low-melting electrolytes with the saturation of $4-5.5$ wt.\% of $\mathrm{Al}_{2} \mathrm{O}_{3}$. This difference is fundamental. In alumina-rich and particularly in suspended melts, the concentration component of polarisation is negligible. However, there is diffusion polarisation, which develops with an increase in the electrolyte viscosity and diffusion cathode layer thickness.

The alumina concentration $c_{0}$ and the diffusion layer thickness $\delta$ have the opposite effect on the maximum current density and cathode potential (equations (10) and (13)). When $C_{0}$ changes, $\delta$ changes, but not vice versa. In the standard melts, this one-way and indirect correlation through changes in the electrolyte viscosity becomes noticeable only in the hypereutectic region of the $\mathrm{NaF}-\mathrm{AlF}_{3}$ system and upon reaching the $\mathrm{Al}_{2} \mathrm{O}_{3}$ concentrations of $9-10 \mathrm{~mol} . \%$ [6]. On the other hand, the influence of $\delta$ on the electrolysis kinetics is stronger and depends on the hydrodynamic conditions in the interelectrode gap. These conditions, including the diffusion layer thickness, can differ throughout the electrode area. Negative consequences for cur- rent density distribution enhance with an increase in the electrolyte viscosity, a decrease of convective stirring, i.e., with an increase in the diffusion layer thickness $\delta$ (fig. 12).

The latter applies fully to the low-melting electrolytes of the $\mathrm{KF}-\mathrm{AlF}_{3}$ system with limited solubility of $\mathrm{Al}_{2} \mathrm{O}_{3}$ and especially to the melts suspended in alumina. Furthermore, in these systems with relatively high viscosity, the extremely low diffusion currents do not permit the electrolysis with the current density higher than $0.5 \mathrm{~A} / \mathrm{cm}^{2}$ on the metal electrodes [8-10] and a fortiori on the polycrystalline surfaces. In the literature, there is an opinion that the inert anodes should operate at current densities of approximately $1.2 \mathrm{~A} / \mathrm{cm}^{2}$ [11] to maintain the heat balance of the electrolysis cells.

With a relatively low increase in $\delta$ from 60 to 75 and $85 \mu \mathrm{m}$, the overall voltage will increase to the discharge potentials of the impurities that are more electronegative than aluminium, i.e., sodium and calcium (see fig. 12). If the latter can passivate the electrode after interaction with the cathode material, its impurities and electrolyte, then $\mathrm{Na}$ will pollute aluminium (carbon cathode) or interact, for example, with the $\mathrm{TiB}_{2}$ cathode surface to form the borates:

$$
\begin{gathered}
\mathrm{TiB}_{2}+8 \mathrm{Na}(\mathrm{g})+4.5 \mathrm{O}_{2}(\mathrm{~g}) \rightarrow \\
\rightarrow \mathrm{Na}_{4} \mathrm{TiO}_{4}+\mathrm{Na}_{4} \mathrm{~B}_{2} \mathrm{O}_{5}(\mathrm{l}) ; \\
\Delta G^{0}{ }_{T}=-3528.4 \mathrm{~J} / \mathrm{mol} .
\end{gathered}
$$

The authors believe [12] that the products of this interaction can dissolve in the electrolyte, hence increasing the micro-defects and stimulating electrode corrosion.

In conclusion, we report the calculation results of the current density and potential distribution depending on the height of the physical defects (fig. 13).

In the range of the roughness height from 0.1 to $1 \mathrm{~mm}$ (simulating the heterogeneity development) the current density on the defect peaks reaches limiting values, and potential approaches possible decomposition of the electrolyte components and cathode passivation. As expected, this trend has more pronounced negative effects on the cathode processes. To a certain extent, one can control the electrolysis parameters discussed above $\left(i_{A}, C_{0}, \beta, \delta\right)$ and 


\begin{tabular}{c} 
Металлургия и материаловедение \\
Metallurgy and Materials Science \\
\hline
\end{tabular}

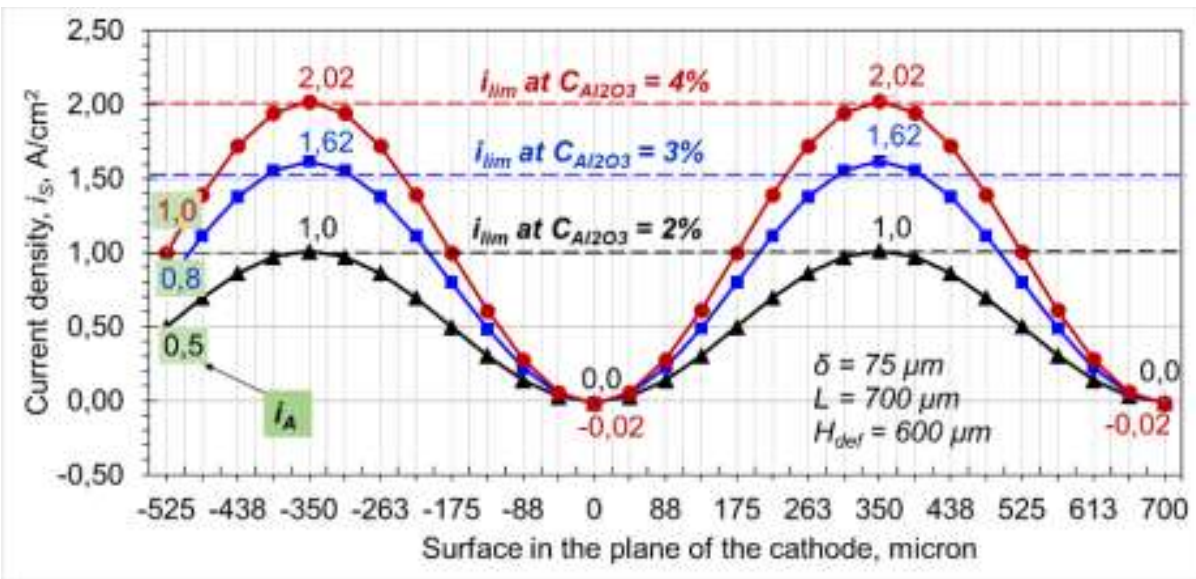

Fig. 11. Distribution of $i_{S}$ at initial $i_{A}$ of $0.5,0.8$ and $1.0 \mathrm{~A} / \mathrm{cm}^{2}$

Puc. 11. Распределение $i_{S}$ при исходной $i_{A}$ равной $0.5,0.8$ и $1.0 \mathrm{~A} / \mathrm{cm}^{2}$

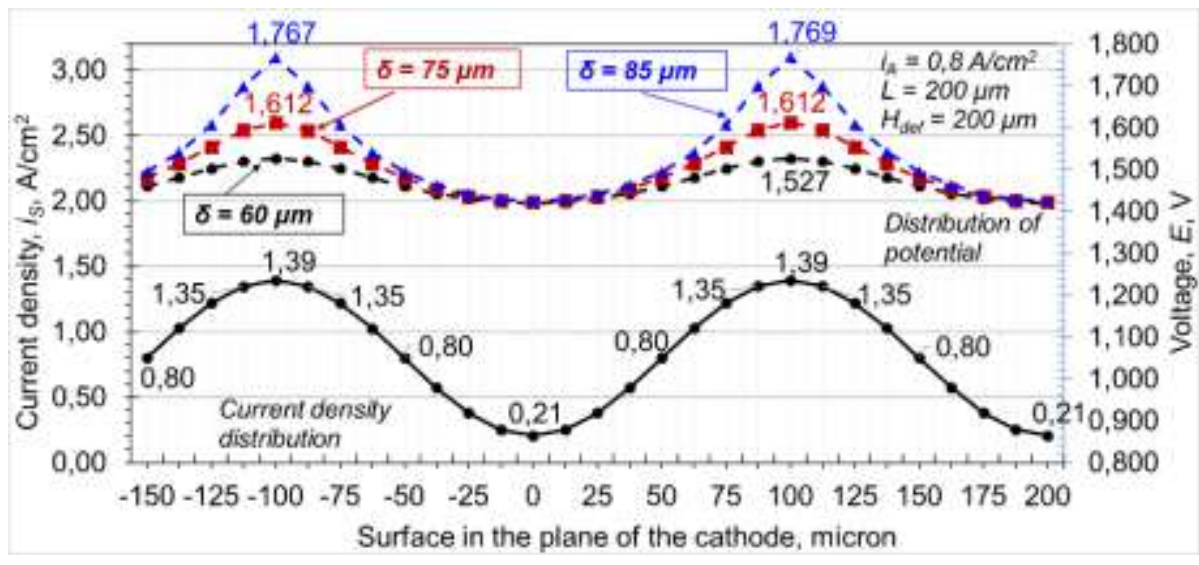

Fig. 12. Influence of $\delta$ on the $E$ distribution Puc. 12. Влияние $\delta$ на распределение $E$

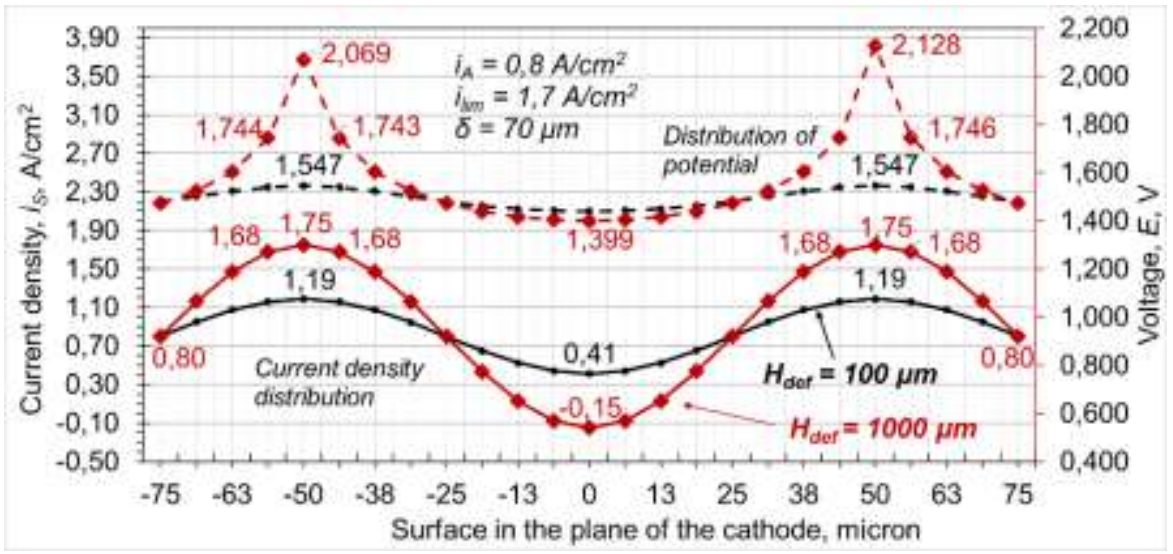

Fig. 13. Impact of the height of the defect on the distribution of is (continuous) and $E$ (dashed) Puc. 13. Влияние высоты дефектов на распределение іs (сплошная) и $E$ (пунктирная)

select technologically and constructively the optimum conditions for the operation of the electrodes. Physical and chemical heterogeneity is more difficult to influence in the manufacture of electrodes by moulding or casting. Attempts to change/reduce initial roughness by mechanical methods, such as surface polishing, affect only the electrode start-up. The roughness parameters and the impurity profile of items change during the start-up and working cycle. More pre- 
cisely, the presence or propagation of chemical heterogeneity of the surface and/or bulk of the item leads to physical heterogeneity during the electrode working cycle.

Notably, aluminium can discharge on the entire surface, including the recesses (see fig. 9-13). However, kinetically, i.e., without current and overpotential in the recesses, this process barely occurs, more precisely, it proceeds under equilibrium conditions. When present in the melt, conditions for discharge in the cavities are more favourable for electropositive ions. This element is boron, which is almost twice as electropositive as aluminium. Boron, if reduced in a recess, reacts, for example, with titanium or titanium oxide, and the resulting titanium diboride will flatten any inhomogeneities.

Thus, the functional relationship among the following parameters was established by simulating different scenarios of the interaction of the cathode polarisation level, geometric current density, stirring intensity (by $\delta$ ) and the alumina concentration in the electrolyte on the smooth and rough surface:

The pronounced edge effect of current concentration, i.e., an increase in its density, is observed on the periphery of the nominally smooth electrodes and their internal perforated elements. The current and potential concentration on the edges, side surfaces of the openings and rods increases the cathode passivation or the anode consumption proportional to their total area.

An increase in the initial or acquired during the electrolysis surface defects of electrodes leads to the progressive heterogeneity of the current and potential distribution, increases the risk of the cathode passivation and/or electrochemical anode corrosion.

An elevation of the current alumina concentration in the electrolyte relative to its maximum content augments the limiting current density, but at the same time:

- deteriorates the scattering properties of the melt and the current micro-distribution on the micro-defects;

- increases the melt viscosity, diffusion nearcathode layer, consequently, gradually decreases the limiting current density.

The surface polarisation smooth out the cur- rent distribution on the smooth and polycrystalline electrodes.

The intensification of the melt stirring, i.e., decreasing the diffusion layer thickness and levelling the concentration of the potentialdetermining ions in the electrolyte volume, increases maximum current density, equalises distribution and diminishes the absolute values of the electrode potential.

It is possible to reduce the heterogeneous current and potential distribution on the electrode surface with initial roughness by increasing the cathode polarisation, optimising the alumina concentration and melt circulation. However, initial physical heterogeneity can progress with the prolonged electrolysis in the presence of chemical heterogeneity, undermining all attempts to stabilise the process.

\section{CONCLUSIONS}

The above-discussed relationship between the edge effect and roughness and the current density and potential distribution over solid electrodes can act as a primary and unifying factor for their increased consumption, passivation and electrolytic process destabilisation in standard and low-melting electrolytes $\mathrm{NaF}(\mathrm{KF})-\mathrm{AlF}_{3}$ $\mathrm{Al}_{2} \mathrm{O}_{3}$. Nevertheless, this functional relationship can form the basis for developing the methods of equalising the electric field distribution over the anodes and cathodes area and, therefore, stabilising the electrolytic process. Presumably, the reduction in the number of components, elements and units of the electrode with sharp or chamfered edges and joints is one important condition to diminish the negative effects of current density at the edges. Any bulging parts and perforations within the electrode geometry should be excluded. However, the current is distributed over the area of solid electrodes in such a manner that the current density increases from the centre to the perimeter with the accumulation at the edges of the cathode and anode (fig. 7 and fig. 8). Possibly, a similar and adequate increase in resistance in the pole gap will minimise this effect on the periphery so that the current density does not change in width and over the area of electrodes. The elliptic form of electrodes with an acceptable increase in the pole gap from the centre to the periphery satisfies 
these conditions. When the electrodes are vertically positioned, both the anode and cathode should be shaped elliptical in cross-section, while with the horizontal arrangement of electrodes - only the inert anode. For example, in [13], the nature of the corrosion in the oxygenreleasing anodes was investigated in the $\mathrm{NaF}-$ 53.6, $\mathrm{AlF}_{3}-41.2, \mathrm{CaF}_{2}-4.0, \mathrm{MgF}_{2}-1.2$ (wt.\%) melts at the current density of $0.5 \mathrm{~A} / \mathrm{cm}^{2}$ and the temperature of $960^{\circ} \mathrm{C}$ for $50-150$ hours. An aluminium layer on the bottom of the crucible was used as the cathode.

Regardless of the composition, the anode deterioration proceeded with a higher rate in the samples along the sharp peripheral edge $(D)$. The samples with the elliptic side surface underwent uniform corrosion $(E)$.

However, only a special shape is not sufficient to conduct a stable process using solid electrodes, polycrystalline and cast, singlephase and multiphase, which a priori have physical and chemical heterogeneity in their bulk and surface structure. In the work [14], electrochemical micro-borating of carbon cathodes containing refractory metals and their oxides was proposed as one method of surface homogenisation directly in the electrolysis process. The same method can be applied virtually to any reactive or inert cathodes with the surface heterogeneity smoothed by the chemical interaction of boron with the present impurities, hence equalising the surface physical state.

Thus, based on a relatively detailed examination and analysis of the problems of solidcathode electrolysis - literature review, laboratory practice and theoretical calculations - a simple procedure for the electrolysis process has been elaborated: combined application of elliptical electrodes and electrochemical microborating of the cathodes. The validation of this method is one of the possible areas of further theoretical and laboratory research. It could also be one of the last attempts at commercialising inert electrode technology. The latter relates to several factors:

- The expectation of environmental and economic benefits from introducing inert electrode technology has been delayed. The closure of the project is stopped by huge funds that have not paid for themselves, invested in more than 70 years of technology development.

- Simple recommendations for process temperature reduction, electrode and electrolyte composition corrections [15-20] do not allow implementation in the industry;

- Current technologies have come close to the technological and economic indicators expected from introducing the inert electrode technology. The urge to continue work on inert anodes is being questioned [21];

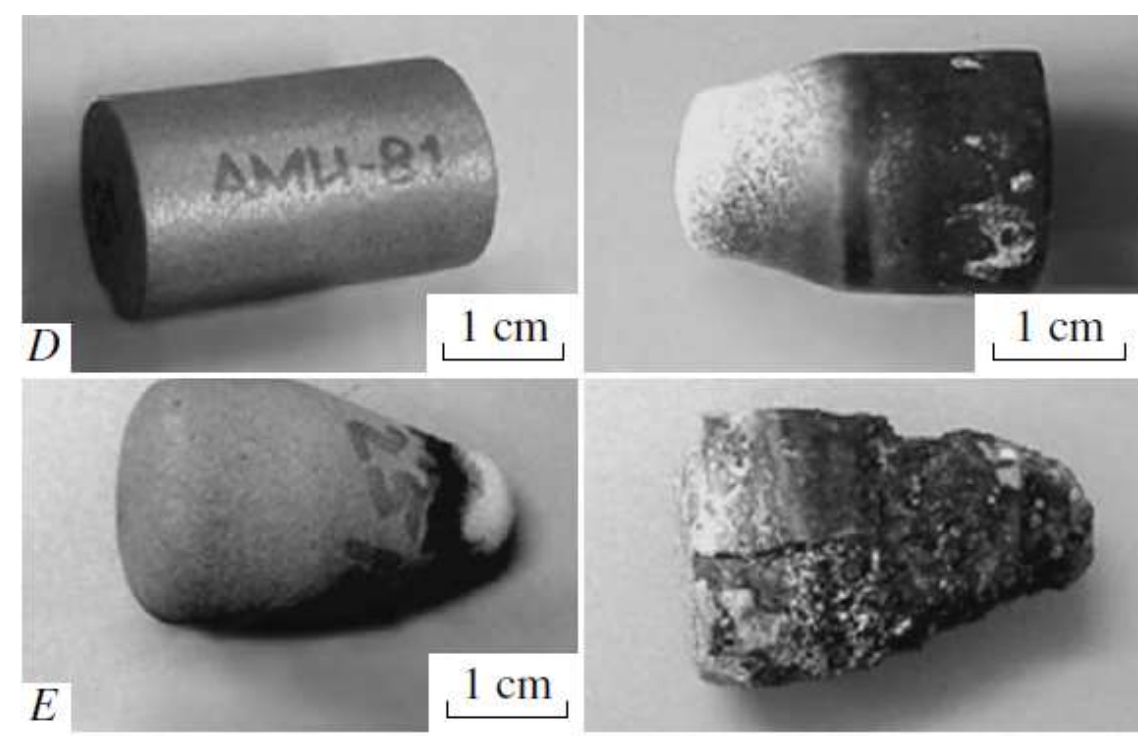

Fig. 14. Inert anode samples before (left) and after (right) the electrolysis [13] (D) $\mathrm{NiFe}_{2} \mathrm{O}_{4}$-NiO-Cu cermet and (E) the metal-cermet composite

Puc. 14. Образцы инертных анодов до (слева) и после (справа) электролиза [13] (D) $\mathrm{NiFe}_{2} \mathrm{O}_{4}$-NiO-Cu металлокерамика и (E) металл-керметный композит 
- Greenhouse gas capture and separation technologies such as carbon capture and sequestration are highly standardised and ready for use [22-25];

- New directions and methods of aluminium electrolytic production appear, associated with the utilization of "waste" energy, saving energy resources and increasing production per unit of working space of the cell [26];

- There is no complete understanding of the impact of the local excess of oxygen in the atmosphere on human and the environment, as well as of fire safety in the major oxygen source area, for example, the aluminium plant with inert anodes. With increasing the oxygen partial pressure in the atmosphere, the initial flash point, at which the vapours can ignite, lowers. In such an atmosphere, the fire can start with the spark generated by the friction of synthetic clothing with the human body [27].

However, in the near future, electrolysis of cryolite-alumina melts will remain the major industrial method of aluminium production. The ecology and electric power deficiency and their economic parameters encourage researchers to improve existing and develop new technologies. Potentially, we are at the turn of creating a new "Roadmap" of the development of the aluminium industry.

\section{References}

1. Kruglikov SS, Titova NV, Nekrasova NE, Kruglikova ES, Telezhkina AV, Brodsky VA, et al. Predicting microdistribution rate of metal electrodeposition from electrolytes with positive and negative leveling ability. Elektrokhimiya. 2019;55(1):78-84. (In Russ.) https://doi.org/10.1134/S0424857018140050

2. Ibl N. Current Distribution. In: Yeager E, Bockris JO, Conway BE, Sarangapani S (eds.). Comprehensive treatise of electrochemistry. Boston: Springer; 1983, p. 239315. https://doi.org/10.1007/978-1-4615-6690-8_4

3. Newman J, Thomas-Alyea KE. Electrochemical systems. 3rd ed. New Jersey: Published by John Wiley \& Sons; 2004, $647 \mathrm{p}$.

4. Gamburg YD, Zangari G. Theory and practice of metal electrodeposition, 2019, 439 p. (Russ. ed.: Teoriya i praktika elektroosazhdeniya metallov. Moscow. Binom, Laboratoriya znanij, 2019, 439 p.)

5. Baraboshkin NA. Electrocrystallization of metals from molten electrolytes. Moscow: Nauka; 1976, 279 p. (In Russ.)

6. Vetyukov MM, Tsyplakov AM, Shkolnikov SN. Metallurgy of aluminum and magnesium. Moscow: Metallurgiya; 1987, 320 p. (In Russ.)

7. Grjotheim K, Krohn C, Malinovsky M, Matiasovsky K, Thonstad J. Aluminium electrolysis fundamentals of the Hall-Heroult process. 2nd ed. Dusseldorf: AluminiumVerlag; 1982, p. 360.

8. Nikolaev AYu, Yasinskiy AS, Suzdaltsev AV, Polyakov $\mathrm{PV}$, Zaikov YuP. Aluminum Electrolysis in the $\mathrm{KF}^{-\mathrm{AlF}_{3}-}$ $\mathrm{Al}_{2} \mathrm{O}_{3}$ Melts and Suspensions. Rasplavy. 2017;3:205-213. (In Russ.)

9. Nikolaev AYu, Yasinskiy AS, Suzdaltsev AV, Polyakov $\mathrm{PV}$, Zaikov YuP. Voltammetry in the $\mathrm{KF}^{-} \mathrm{AlF}_{3}-\mathrm{Al}_{2} \mathrm{O}_{3}$ Melt and Suspensions. Rasplavy. 2017;3:214-224. (In Russ.) 10. Nikolaev AYu, Suzdaltsev AV, Zaikov YuP. Cathode Process in the $\mathrm{KF}^{-}-\mathrm{AlF}_{3}-\mathrm{Al}_{2} \mathrm{O}_{3}$ Melts. Journal of the Electrochemical Society. 2019;166(15):D784-D791. https://doi.org/10.1149/2.0521915jes
11. De Nora $V$, Nguyen $T$. Inert anode: Challenges from fundamental research to industrial application. In: Light Metals - 2009: Proceedings of the Technical Sessions Presented by the TMS Aluminum Committee at the TMS 2009 Annual Meeting and Exhibition. 15-19 February 2009, San Francisco. San Francisco; 2009, p. 417-421.

12. Wang Zhaohui, Friis J, Ratvik AP. Transport of Sodium in $\mathrm{TiB}_{2}$ Materials Investigated by a Laboratory Test and DFT Calculations. In: Martin O (eds.). Light Metals 2018. TMS 2018: The Minerals, Metals \& Materials Series. Cham: Springer; 2018, p. 1321-1328. https://doi.org/10.1007/978-3-319-72284-9_173

13. Kovrov VA, Shurov NI, Khramov AP, Zaikov YuP. Character of the corrosion destruction of inert anodes during electrolysis of cryolite alumina melt and the reasons for it. Russian Journal of Non-Ferrous Metals. 2009;50(5):492-499. https://doi.org/10.3103/S1067821209050113

14. Gorlanov ES. On the question of using solid electrodes in the electrolysis of cryolite-alumina melts. Part 2. The mechanism of passivation and conditions of stable electrolysis. Vestnik Irkutskogo gosudarstvennogo tehnicheskogo universiteta $=$ Proceedings of Irkutsk State Technical University. 2021;25(1):108-121. https://doi.org/10.21285/1814- 3520-2021-1-108-121

15. Brown CW. The wettability of $\mathrm{TiB}_{2}$-based cathodes in low-temperature slurry-electrolyte reduction cells. JOM. 1998;50(5):38-40.

16. Wang J, Lai $Y$, Tian Z, Liu Y. Investigation of $5 \mathrm{Cu}$ $\left(10 \mathrm{NiO}-\mathrm{NiFe}_{2} \mathrm{O}_{4}\right)$ inert anode corrosion during low temperature aluminum electrolysis. In: Light Metals - 2007: Proceedings of the Technical Sessions Presented by the TMS Aluminum Committee at the TMS 2007 Annual Meeting and Exhibition. Part 2. 25 February - 1 March 2007, Orlando. Orlando; 2007, p. 525-530.

17. Zaikov Yu, Khramov A, Kovrov V, Kryukovsky V, Apisarov A, Chemesov O, et al. Electrolysis of aluminum in the low melting electrolytes based on potassium cryo- 
lite. In: Light Metals - 2008: Proceedings of the Technical Sessions Presented by the TMS Aluminum Committee at the TMS 2008 Annual Meeting and Exhibition. Part 2. 912 March 2008, New Orleans. New Orleans; 2008, p. 505-508.

18. Tkacheva O, Hryn J, Spangenberger J, Davis B, Alcorn T. Operating Parameters of Aluminum Electrolysis in a KF-AIF ${ }_{3}$ BASED Electrolyte. In: Suarez CE (eds.). Light Metals. Cham: Springer; 2012, p. 675-680. https://doi.org/10.1007/978-3-319-48179-1_116

19. Hryn JN, Tkacheva OY, Spangenberger JS. UltraHigh-efficiency aluminum production cell. In: Report of Energy Systems Division, Argonne National Laboratory. Award Number: DE-AC0206CH11357. April 2014. P. 86. Available from: https://www.energy.gov/eere/amo/downloads/ultrahigh-

efficiency-aluminum-production-cells [Accessed 19th August 2020].

20. Bao Shengzhong, Chai Dengpeng, Shi Zhirong, Wang Junwei, Liang Guisheng, Zhang Yanan. Effects of Current Density on Current Efficiency in Low Temperature Electrolysis with Vertical Electrode Structure. In: Martin O (eds.). Light Metals. 2018. TMS 2018: The Minerals, Metals \& Materials Series. Cham: Springer; 2018, p. 611-619 https://doi.org/10.1007/978-3-319-72284-9_79

21. Solheim A. Inert Anodes - the Blind Alley to Environmental Friendliness? In: Martin $\mathrm{O}$ (eds.). Light Metals 2018. TMS 2018: The Minerals, Metals \& Materials Series. Cham: Springer; 2018, p. 1253-1260. https://doi.org/10.1007/978-3-319-72284-9_164
22. Sheppard MC, Socolow RH. Sustaining fossil fuel use in a carbon-constrained world by rapid commercialization of carbon capture and sequestration. American Institute of Chemical Engineers Journal. 2007;53(12):3022-3028. https://doi.org/10.1002/aic.11356

23. Lorentsen O-A, Dyrøy A, Karlsen M. Handling $\mathrm{CO}_{2} \mathrm{EQ}$ from an Aluminum Electrolysis Cell. In: Light Metals 2009: Proceedings of the Technical Sessions Presented by the TMS Aluminum Committee at the TMS 2009 Annual Meeting and Exhibition. 15-19 February 2009, San Francisco. San Francisco; 2009, p. 263-268. https://doi.org/10.1002/9781118647851.ch144 24. Jilvero $H$, Mathisen $A$, Eldrup $\mathrm{N}-\mathrm{H}$, Normann $\mathrm{F}$, Johnsson F, Müller GI, Melaaen MC. Techno-economic Analysis of Carbon Capture at an Aluminum Production Plant - Comparison of Post-combustion Capture Using MEA and Ammonia. Energy Procedia. 2014;63:65906601. https://doi.org/10.1016/j.egypro.2014.11.695

25. Matteucci ST, Lopez LC, Feist ShD, Nickias P, Harrise WJ. Separation of acid components using self-organising polymer membranes. Patent RF, no. 2534772; 2014. (In Russ.)

26. Gorlanov ES, Kawalla R, Polyakov AA. Electrolytic production of aluminium. Review. Part 2. Development prospects. Tsvetnye Metally. 2020;10:42-49. (In Russ.) https://doi.org/10.17580/tsm.2020.10.06

27. Marshall VC. Major chemical hazards, 1989, 671 p. (Russ. ed.: Osnovnye opasnosti himicheskih proizvodstv. Moscow, Mir, 1989, 671 p.)

\section{Список литературы}

1. Кругликов С.С., Титова Н.В., Некрасова Н.Е., Кругликова Е.С., Тележкина А.В., Бродский В.А. [и др.] Прогнозирование микрораспределения скорости электроосаждения металла из электролитов с положительной и отрицательной выравнивающей способностью // Электрохимия. 2019. Т. 55. № 1. С. 78-84. https://doi.org/10.1134/S0424857018140050

2. Ibl N. Current Distribution // Comprehensive Treatise of Electrochemistry / eds. E. Yeager, J.O. Bockris, B.E. Conway, S. Sarangapani. Boston: Springer; 1983, p. 239315. https://doi.org/10.1007/978-1-4615-6690-8_4

3. Newman J., Thomas-Alyea K.E. Electrochemical systems. 3rd ed. New Jersey: Published by John Wiley \& Sons, 2004. 647 p.

4. Гамбург Ю.Д., Зангари Дж. Теория и практика электроосаждения металлов: монография / пер. с англ. Ю.Д. Гамбург. М.: Бином, Лаборатория знаний, 2019. $439 \mathrm{c}$.

5. Барабошкин Н.А. Электрокристаллизация металлов из расплавленных электролитов. М.: Наука, 1976. 279 с. 6. Ветюков М.М., Цыплаков А.М., Школьников С.Н. Металлургия алюминия и магния. М.: Металлургия, 1987. $320 \mathrm{c}$.

7. Grjotheim K., Krohn C., Malinovsky M., Matiasovsky K., Thonstad J. Aluminium electrolysis fundamentals of the Hall-Heroult process. 2nd ed. Dusseldorf: AluminiumVerlag, 1982. $360 \mathrm{p}$.
8. Николаев А.Ю., Ясинский А.С., Суздальцев А.В., Поляков П.В., Зайков Ю.П. Электролиз алюминия в

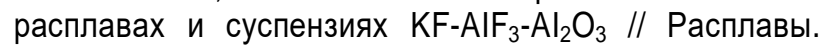
2017. № 3. C. 205-213.

9. Николаев А.Ю., Ясинский А.С., Суздальцев А.В., Поляков П.В., Зайков Ю.П. Вольтамперометрия в расплаве и суспензиях KF-AIF $-\mathrm{Al}_{2} \mathrm{O}_{3} / /$ Расплавы. 2017. № 3. C. 214-224.

10. Nikolaev A.Yu., Suzdaltsev A.V., Zaikov Yu.P. Cathode process in the KF-AlF $-\mathrm{Al}_{2} \mathrm{O}_{3}$ melts // Journal of the Electrochemical Society. 2019. Vol. 166. No. 15. P. D784D791. https://doi.org/10.1149/2.0521915jes

11. De Nora V., Nguyen T. Inert anode: Challenges from fundamental research to industrial application // Light Metals - 2009: Proceedings of the Technical Sessions Presented by the TMS Aluminum Committee at the TMS 2009 Annual Meeting and Exhibition (San Francisco, 1519 February, 2009). San Francisco, 2009. P. 417-421.

12. Wang Zhaohui, Friis J., Ratvik A.P. Transport of sodium in TiB2 materials investigated by a laboratory test and DFT calculations // Light Metals 2018. TMS 2018: The Minerals, Metals \& Materials Series / eds. O. Martin. Cham: Springer, 2018. P. 1321-1328. http://doi.org/10.1007/978-3-319-72284-9_173

13. Kovrov V.A., Shurov N.I., Khramov A.P., Zaikov Yu.P. Character of the corrosion destruction of inert anodes during electrolysis of cryolite alumina melt and the rea- 
sons for it // Russian Journal of Non-Ferrous Metals. 2009. Vol. 50. No. 5. P. 492-499.

https://doi.org/10.3103/S1067821209050113

14. Горланов Е.С. К вопросу о применении твердых электродов для электролиза криолитоглиноземных расплавов. Часть 2. Механизм пассивации и условия стабильного электролиза // Вестник Иркутского государственного технического университета. 2021. Т. 25. № 1. С. 108-121. https://doi.org/10.21285/1814-35202021-1-108-121

15. Brown C.W. The wettability of $\mathrm{TiB}_{2}$-based cathodes in low-temperature slurry-electrolyte reduction cells // JOM. 1998. Vol. 50. Iss. 5. P. 38-40.

16. Wang J., Lai Y., Tian Z., Liu Y. Investigation of $5 \mathrm{Cu}$ $\left(10 \mathrm{NiO}-\mathrm{NiFe}_{2} \mathrm{O}_{4}\right)$ inert anode corrosion during low temperature aluminum electrolysis // Light Metals - 2007: Proceedings of the Technical Sessions Presented by the TMS Aluminum Committee at the TMS 2007 Annual Meeting and Exhibition (Orlando, 25 February - 1 March 2007). Part 2. Orlando, 2007. P. 525-530.

17. Zaikov Yu., Khramov A., Kovrov V., Kryukovsky V., Apisarov A., Chemesov O., et al. Electrolysis of aluminum in the low melting electrolytes based on potassium cryolite // Light Metals - 2008: Proceedings of the Technical Sessions Presented by the TMS Aluminum Committee at the TMS 2008 Annual Meeting and Exhibition (New Orleans, 9-12 March 2008). Part 2. New Orleans, 2008. P. 505-508.

18. Tkacheva O., Hryn J., Spangenberger J., Davis B., Alcorn T. Operating parameters of aluminum electrolysis in a KF-AIF3 BASED electrolyte // Light Metals / eds. C.E. Suarez. Cham: Springer, 2012. P. 675-680. https://doi.org/10.1007/978-3-319-48179-1_116

19. Hryn J.N., Tkacheva O.Y., Spangenberger J.S. UltraHigh-efficiency aluminum production cell // Report of Energy Systems Division, Argonne National Laboratory. Award Number: DE-AC02-06CH11357. April 2014. P. 86. [Электронный ресурс]. URL:

https://www.energy.gov/eere/amo/downloads/ultrahighefficiency-aluminum-production-cells (19.08.2020).

20. Bao Shengzhong, Chai Dengpeng, Shi Zhirong, Wang Junwei, Liang Guisheng, Zhang Yanan. Effects of current density on current efficiency in low temperature electroly-

\section{INFORMATION ABOUT THE AUTHORS}

\section{Evgeniy S. Gorlanov,}

Dr. Sci. (Eng.),

Deputy General Director of EXPERT-AL LLC,

86/A, Sredniy pr., V.O. Saint-Petersburg 199106, Russia;

e-mail: gorlanove@yandex.ru

\author{
Andrey A. Polyakov, \\ Postgraduate Student \\ Saint Petersburg Mining University, \\ 9/30 Transportny lane, Saint Petersburg 191119, Russia; \\ e-mail: polyakovandrej@yandex.ru
}

sis with vertical electrode structure // Light Metals 2018. TMS 2018: The Minerals, Metals \& Materials Series / eds. O. Martin. Cham: Springer, 2018. P. 611-619. https://doi.org/10.1007/978-3-319-72284-9_79

21. Solheim A. Inert anodes - the blind alley to environmental friendliness // Light Metals 2018. TMS 2018: The Minerals, Metals \& Materials Series / eds. O. Martin. Cham: Springer, 2018. P. 1253-1260. https://doi.org/10.1007/978-3-319-72284-9_164

22. Sheppard M.C., Socolow R.H. Sustaining fossil fuel use in a carbon-constrained world by rapid commercialization of carbon capture and sequestration // American Institute of Chemical Engineers Journal. 2007. Vol. 53. Iss. 12. P. 3022-3028. https://doi.org/10.1002/aic.11356

23. Lorentsen O.-A., Dyrøy A., Karlsen M. Handling $\mathrm{CO}_{2} \mathrm{EQ}$ from an aluminum electrolysis cell // Light Metals - 2009: Proceedings of the Technical Sessions Presented by the TMS Aluminum Committee at the TMS 2009 Annual Meeting and Exhibition (San Francisco, 15-19 February, 2009). San Francisco, 2009. P. 263-268. https://doi.org/10.1002/9781118647851.ch144

24. Jilvero H., Mathisen A., Eldrup N.-H., Normann F., Johnsson F., Müller G.I., Melaaen M.C. Techno-economic analysis of carbon capture at an aluminum production plant - comparison of post-combustion capture using MEA and ammonia // Energy Procedia. 2014. Vol. 63. P. 6590-6601. https://doi.org/10.1016/j.egypro.2014.11.695 25. Пат. № 2534772, Российская Федерация, МПК B01D 71/48. Отделение кислых компонентов с помощью мембран из самоорганизующегося полимера / С.Т. Маттеуччи, Л.К. Лопес, Ш.Д. Фейст, П. Никиас, У.Дж. Харрис; заявитель и патентообладатель Дау Глобал Текнолоджиз. № 2012139032/05. Заявл. 11.02.2011; опубл. 10.12.2014. Бюл. № 8.34 с.

26. Горланов Е.С., Кавалла Р., Поляков А.А. Электролитическое производство алюминия. Обзор. Часть 2. Перспективные направления развития // Цветные металлы. 2020. № 10. С. 42-49.

https://doi.org/10.17580/tsm.2020.10.06

27. Маршалл В.К. Основные опасности химических производств / пер. с англ. Г.Б. Барсамяна. М.: Мир, 1989. 671 с.

\section{ИНФОРМАЦИЯ ОБ АВТОРАХ}

Горланов Евгений Сергеевич, доктор технических наук, заместитель генерального директора, ООО «ЭКСПЕРТ-АЛ», 199106, г. Санкт-Петербург, Средний просп. В.О., 86/A, Россия;

$\triangle$ e-mail: gorlanove@yandex.ru

\section{Поляков Андрей Александрович,} аспирант,

Санкт-Петербургский горный университет,

191119, г. Санкт-Петербург, Транспортный пер., 9/30, Россия;

e-mail: polyakovandrej@yandex.ru 


\section{Contribution of the authors}

Gorlanov E.S. was responsible for conceptualization, methodology, calculations, copywrighting. Polyakov A.A. performed the research, analyzed the literature, processed and verified data, wrote the text of the article.

\section{Conflict of interests}

The authors declare no conflict of interests.

The final manuscript has been read and approved by all the co-authors.

Information about the article

The article was submitted 02.02.2021; approved after reviewing 17.03.2021; accepted for publication 29.04.2021.

\section{Заявленный вклад авторов}

Горланов Е.С. - концептуализация, методология, расчеты, написание текста. Поляков А.А. - исследование, анализ литературы, обработка и проверка данных, написание текста.

\section{Конфрликт интересов}

Авторы заявляют об отсутствии конфрликта интересов.

Все авторы прочитали и одобрили окончательный вариант рукописи.

\section{Информация о статье}

Статья поступила в редакцию 02.02.2021; одобрена после рецензирования 17.03.2021; принята к публикации 29.04.2021. 